\title{
H2, a Temperate Bacteriophage Isolated from Bacillus amyloliquefaciens Strain $\mathbf{H}$
}

\author{
By S. A. ZAHLER, ${ }^{*}$ R. Z. KORMAN, C. THOMAS, P. S. FINK, \\ M. P. WEINER AND J. M. ODEBRALSK I \\ Section of Genetics and Development, Division of Biological Sciences, Cornell University, \\ Ithaca, New York 14853, USA
}

(Received 20 March 1987; revised 28 May 1987)

Bacillus amyloliquefaciens strain $\mathrm{H}$ is lysogenic for a large temperate phage we call $\mathrm{H} 2 . \mathrm{H} 2$ has a polyhedral head $85 \mathrm{~nm}$ in diameter and a tail of about $17 \times 434 \mathrm{~nm}$. H2 lysogenizes Bacillus subtilis between the tyrA and met $B$ genes, and gives specialized transduction of met $B$ and, at lower frequencies, of ilv $D$ and ilv $A$. The phage carries a thymidylate synthase gene and converts thymine auxotrophs of $B$. subtilis to prototrophy. The $\mathrm{H} 2$ genome is a linear DNA molecule about $129 \mathrm{~kb}$ in length. DNA extracted from phage particles grown in $B$. subtilis is not cut by the restriction endonucleases $\mathrm{HaelII}, F n u 4 \mathrm{HI}, B s p 1286 \mathrm{I}$, and $B a m \mathrm{HI}$; the latter enzyme is produced by $B$. amyloliquefaciens strain $\mathrm{H}$. The prophage in lysogenic $B$. subtilis cells can be cut by these enzymes. We have isolated $\mathrm{H} 2$ mutants that carry the transposon $\mathrm{Tn} 917$, or a mutation resulting in clear-plaque morphology, or both.

\section{INTRODUCTION}

We have studied temperate bacteriophage production in several strains of Bacillus amyloliquefaciens, a bacterium of ten used in industrial fermentations (Zahler et al., 1987), and have selected a phage released by strain $\mathrm{H}$ for detailed examination; this phage was named phage $\mathrm{H} 2$.

Phage $\mathrm{H} 2$ can carry out specialized transduction of bacterial genes close to its attachment site on the $B$. subtilis chromosome. It is of potential use in mediating gene transfer in $B$. amyloliquefaciens.

\section{METHODS}

Bacterial strains. The bacteria used in this study are listed in Table 1.

Culture conditions. Bacteria were grown in modified M Broth (MMB, Warner et al., 1977). Solid medium was tryptose blood agar base (TBAB, Difco). Overlay agar for plaques was TBA (Rosenthal et al., 1979). Plaque counts of $\mathrm{H} 2$ lysates were made in $3 \mathrm{ml}$ TBA overlays with exponential-phase cells of CU3431, poured over TBAB plates containing $40 \mu \mathrm{g}$ thymidine $\mathrm{ml}^{-1}$ and incubated at $30^{\circ} \mathrm{C}$. Other incubations were done at $37^{\circ} \mathrm{C}$ with suitable aeration, unless otherwise specified. Synthetic agar medium was that of Anagnostopoulos \& Spizizen (1961). Thymidine $\left(40 \mu \mathrm{g} \mathrm{ml}^{-1}\right)$ was added to all media in which strain CU3431 was grown. Selection for MLS ${ }^{\mathrm{R}}$ was made on TBAB containing $1 \mu \mathrm{g}$ erythromycin and $25 \mu \mathrm{g}$ lincomycin $\mathrm{ml}^{-1}$.

Preparation of phage stocks. Methods for preparing phage SP $\beta$ were described by Fink et al. (1981). The generalized transducing phage PBS1 was prepared by our usual methods (Ward \& Zahler, 1973).

We produced satisfactory H2 lysates either by harvesting phage from agar plates (using strain CU3431 as plating bacteria), by growing the phage lytically in cultures of strain CU3431, or by inducing the lysogenic strain CU7004. The first two methods were used primarily for the production of lysates of the clear-plaque mutant $\mathrm{H} 2 c 21$. The induction of CU7004 was most satisfactory for the production of lysates of $\mathrm{H} 2$. The following protocol resulted in high-titre lysates suitable for DNA extraction.

Abbreviation: MLS, macrolide-lincosamide-streptogramin B. 
Table 1. Bacterial strains

Bacterial strain*

Genotype

Notes

\begin{tabular}{|c|c|}
\hline CU1050† & leu-1050 thr A5 metB5 sup-3 \\
\hline CU1064 & $\operatorname{met} B 5$ \\
\hline CU1065 & $\operatorname{trpC2}$ \\
\hline CU1103 & citK1 leuB6 metB5 pheA2 \\
\hline CU1331 & met $B 10$ ilvA2 \\
\hline CU1354 & $\arg C 4$ metBS \\
\hline CU1920 & $\arg A 2$ met $B 5$ phe $A 2$ \\
\hline CU2958 & metB5 ilvD15 thyB5 ilvA2 thyA5 \\
\hline CU3069† & met $B 5$ \\
\hline CU3431† & metB5 thyBII thy All \\
\hline CU3617 & $\operatorname{trp} C 2(\mathrm{pTV} 1)$ \\
\hline CU7004 & $\operatorname{trpC2}(\mathrm{H} 2)$ \\
\hline CU7040 & metB5 ilvD15 thyB5 ilvA2 thyA5 (H2) \\
\hline CU7048 & met $B 5(\mathrm{H} 2:: \operatorname{Tn} 917-1)$ \\
\hline CU7049 & met $B 5(\mathrm{H} 2:: \operatorname{Tn} 917-2)$ \\
\hline CU7056 & $\operatorname{trpC2}(\mathrm{H} 2)(\mathrm{pTV} 1)$ \\
\hline CU7071† & $\begin{array}{l}\text { metB5 thyB } 11 \text { thy } A 11(\mathrm{H} 2)(\mathrm{H} 2 \\
\mathrm{d} m e t B 201)\end{array}$ \\
\hline CU7075 & $\begin{array}{l}\text { metB5 ilvD15 thyB5 ilvA2 thy } A 5(\mathrm{H} 2) \\
(\mathrm{H} 2 \text { dilvA301) }\end{array}$ \\
\hline CU7077 & $\begin{array}{l}\text { met B5 ilvD15 thyB5 ilvA2 thy } A 5(\mathrm{H} 2) \\
(\mathrm{H} 2 \text { dilvD7) }\end{array}$ \\
\hline CU7082 & $\begin{array}{l}\text { metB5 ilvD15 thyB5 ilvA2 thy } A 5(\mathrm{H} 2) \\
(\mathrm{H} 2 \mathrm{~d} \text { met B205) }\end{array}$ \\
\hline CU8004‡ & B. amyloliquefaciens $(\mathrm{H} 2)$ \\
\hline CU8060 & $(\mathrm{H} 2:: \operatorname{Tn} 917)$ \\
\hline
\end{tabular}

Zahler et al. (1977)

Zahler et al. (1977)

Zahler et al. (1977)

Stock strain

Stock strain

Stock strain

Stock strain

Stock strain

Transformation: CU1065 $\rightarrow$ CU1050 (see text)

Double selection of CU3069 for resistance to trimethoprim (Neuhard et al., 1973)

Stock strain

Zahler et al. (1987)

$\mathrm{H} 2 \rightarrow \mathrm{CU} 2958$

See text

See text

CU3617 $\stackrel{\text { PBSI }}{\longrightarrow}$ CU7004; Selection: $\mathrm{Cm}^{\mathrm{R}}$

CU7004 $\stackrel{\text { H2 }}{\longrightarrow}$ CU2958; Selection: $\mathrm{Met}^{+}$

$\mathrm{IlvD}^{+} \mathrm{IlvA}^{+} \mathrm{Thy}^{+}$

CU7004 $\stackrel{\text { H2 }}{\longrightarrow}$ CU2958; Selection: $\mathrm{Met}^{+}$

$\mathrm{IlvD}^{+} \mathrm{Thy}^{+}$

CU7004 $\stackrel{\text { H2 }}{\longrightarrow}$ CU7040; Selection: Met $^{+}$

$=$ strain $\mathrm{H}$, Welker \& Campbell (1967)

$\mathrm{H} 2:: \operatorname{Tn} 917$ conversion of CU8004;

Selection: MLS

* CU8000 strains are B. amyloliquefaciens. CU7000 strains are B. subtilis lysogenic for phages of $B$. amyloliquefaciens; other CU strains are $B$. subtilis. All $B$. subtilis strains carry an empty attachment site $($ att SP $\beta)$ for phage SP $\beta$.

$\dagger$ These strains carry an unidentified marker named pla-1, originating in CU1050, that improves the ability of SP $\beta$ to form plaques on them if they are Thy ${ }^{+}$, and improves the ability of $\mathrm{H} 2$ to form plaques on them if they are Thy $^{-}$(see Text).

$\ddagger$ Received from Bruce Carlton, University of Georgia, USA.

A sample (100 ml) of the lysogenic strain CU7004 in MMB was grown to an optical density of $25-35 \mathrm{~K}$ lett units (Klett-Summerson colorimeter, red filter; early exponential-phase growth). Mitomycin $\mathrm{C}$ was added to a final concentration of $500 \mathrm{ng} \mathrm{ml} \mathbf{m}^{-1}$. The culture was aerated for an additional $90-120 \mathrm{~min}$, and then refrigerated overnight to permit complete lysis. It was then centrifuged to remove debris.

This phage lysate was then used to infect a non-lysogenic strain (CU3431) by diluting the lysate tenfold into a growing cell culture (25-35 Klett units). The optical density was monitored at $15 \mathrm{~min}$ intervals. At maximum lysis, indicated by the cessation of decline in Klett value for at least $30 \mathrm{~min}$, the cell debris was removed by centrifugation. $\mathrm{NaCl}\left(60 \mathrm{~g} \mathrm{l}^{-1}\right)$ and polyethylene glycol $\left(70 \mathrm{~g}^{-1} ; \mathrm{PEG}-6000\right.$, Fisher Scientific) were added, and the lysate was mixed until the salt and PEG were in solution. This suspension was refrigerated overnight.

The PEG-precipitated bacteriophage was collected by centrifuging the PEG-treated lysate at $4000 \mathrm{~g}$ for $30 \mathrm{~min}$ in a GS3 rotor (Sorvall). It was dissolved in Tris/ $\mathrm{Mg}$ buffer $\left(10 \mathrm{~mm}-\mathrm{Tris} / \mathrm{HCl}, 10 \mathrm{~mm}-\mathrm{MgCl}_{2} \mathrm{pH} 7 \cdot 5\right)$ and layered onto a step gradient consisting of $2.5 \mathrm{ml}$ each of a 1.4 and a 1.6 density $\left(\mathrm{g} \mathrm{cm}^{-3}\right) \mathrm{CsCl}$ solution in a 50Ti centrifuge tube (Beckman). After centrifugation for $90-120 \mathrm{~min}$ at $15^{\circ} \mathrm{C}$ at $100000 \mathrm{~g}$ in a $50 \mathrm{Ti}$ Beckman rotor, the opalescentblue phage band (between the 1.4 and 1.6 density layers) was removed with a Pasteur pipette. An equal volume of saturated $\mathrm{CsCl}$ solution (density 1.9) was added, and the phage was subjected to a second step gradient as described. The phage band was removed and dialysed overnight against 41 Tris/EDTA buffer $(10 \mathrm{~mm}-\mathrm{Tris} / \mathrm{HCl}$, 1 mM-EDTA, pH 7.5).

Extraction and analysis of phage $\mathrm{H} 2 \mathrm{DNA} . \mathrm{H} 2$ phage, purified through two step-gradient centrifugations and dialysed as above, was lysed with sodium dodecyl sulphate (SDS, $0.5 \%$ final concentration) in Tris/EDTA buffer. 
The DNA was extracted with phenol and then with chloroform; the extractions were repeated, and then the DNA was dialysed overnight against 41 Tris/EDTA buffer.

The DNA was analysed with restriction endonucleases using the conditions specified by the enzyme supplier (New England Biolab or BRL). Separation of the DNA fragments, estimation of their sizes, and the production of restriction endonuclease maps of the $\mathrm{H} 2$ genome were done as described by Fink et al. (1981). Size standards of undigested SP $\beta$ and $\lambda$ phage DNAs, of $\lambda$ phage DNA cut with HindIII, and of bacteriophage $\phi$ X174 DNA cut with HaeIII, were run with the experimental samples.

Electron microscopy. $\mathrm{H} 2$ phage particles were dialysed against a $20 \mathrm{mM}$-piperazine- $N$ - $N^{\prime}$-bis[2-ethanesulphonic acid] (PIPES, Sigma)/10 mM- $\mathrm{MgCl}_{2}$ buffer, $\mathrm{pH} \mathrm{8.0.} \mathrm{A} \mathrm{sample} \mathrm{of} \mathrm{the} \mathrm{phage} \mathrm{suspension} \mathrm{was} \mathrm{placed} \mathrm{on} \mathrm{a} \mathrm{Formvar-}$ coated 300 mesh copper grid, and the phage preparation was stained with $1 \%$ (w/v) uranyl acetate $\mathrm{pH} 4.5$ for $60 \mathrm{~s}$. The stained phages were then examined with a Philips EM201 electron microscope.

\section{RESULTS \\ Production of strain CU3431}

We produced lysates of phage $\mathrm{H} 2$ by mitomycin-C-induced lysis of $B$. amyloliquefaciens strain CU8004 ( = strain H), and produced a $B$. subtilis lysogen of $\mathrm{H} 2$ that we call CU7004 (Zahler $e t$ al., 1987). Although $\mathrm{H} 2$ lysates produced faint clearing of overlays of strain CU1050 (our usual plating bacterium for phage SP $\beta$; Rosenthal et al., 1979) or strain CU1065, we could not detect individual plaques. Our final choice as plating host for H2, strain CU3431, was constructed by the following steps. Strain CU1050 was transformed with excess DNA extracted from strain CU1065. Selection was for $\mathrm{Leu}^{+}$. Among the transformants were several that had also lost (by congression) the sup-3 marker present in CU1050; one of those, strain CU3069, had in addition lost the thrA5 marker of CU1050. The known markers of CU3069 are metB5 attSP $\beta$. It differs from other strains with (presumably) the same genotype (e.g., CU1064) in being as good a plating host for SP $\beta$ as is CU1050. Like CU1050, CU3069 gives about 100 times as many SP $\beta$ plaques as do CU1064 or CU1065. We assume that this is due to a genetic marker (pla-1) present in CU1050 that permits good plaque formation. Thus the genotype of CU3069 is considered to be met B5 pla-1. From strain CU 3069 we isolated a thymine auxotroph by the two-step procedure of Neuhard et al. (1973). This strain, CU3431, is a good plating bacterium for $\mathrm{H} 2$, but not for $\mathrm{SP} \beta$; its genotype is metB5 thy A11 thyB11 pla-1. We are not aware of any prophage it carries other than the defective prophage for phage PBSX (see Rutberg, 1982). We do not know why thymine auxotrophy affects the ability of these bacterial strains to produce good plaques with the two phages.

\section{Conversion of $\mathrm{Thy}^{-} \mathrm{B}$. subtilis to $\mathrm{Thy}^{+}$by $\mathrm{H2}$}

When turbid plaques of $\mathrm{H} 2$ growing on strain CU3431 were picked and purified to isolate lysogens, we found that all strains immune to the clear-plaque mutant $\mathrm{H} 2 c 21$ (see below) were also $\mathrm{Thy}^{+}$. The $\mathrm{Thy}^{+}$phenotype was present at $50{ }^{\circ} \mathrm{C}$ as well as at lower temperatures, indicating that the thy $B$ gene of $B$. subtilis (which encodes a thermosensitive thymidylate synthase) is not involved.

Bacteriophage $\mathrm{H} 2$ contains a thermostable thymidylate synthase gene, as do several other Bacillus phages (Tucker, 1969; Dean et al., 1976, 1978; Fernandes et al., 1983). We have labelled the $\mathrm{H} 2$ gene $t h y H 2$. This gene has been subcloned from the bacteriophage to the Escherichia coli plasmid vector pUC19 by complementation of an $E$. coli thy $A:$ : Tn 10 insertion.

\section{Isolation of $\mathrm{H} 2:: \operatorname{Tn} 917$}

Plasmid pTV1 (Youngman et al., 1983) carries a chloramphenicol-resistance gene, a temperature-sensitive replication system, and the Streptococcus faecalis transposon Tn917. The transposon confers resistance to erythromycin and lincomycin. This resistance phenotype is called MLS $^{\mathrm{R}}$ (macrolides, lincosamides, streptogramin B antibiotics). We moved plasmid pTV1 into the $\mathrm{H} 2$ lysogen CU7004 by PBS1 transduction, selecting for chloramphenicol resistance (10 $\mu \mathrm{g}$ chloramphenicol $\mathrm{ml}^{-1}$ ). A CU7004 derivative carrying pTV1, strain CU7056, was grown at $30^{\circ} \mathrm{C}$ to allow transposition of $\mathrm{Tn} 917$ from the plasmid to the bacterial chromosome (including the $\mathrm{H} 2$ prophage). Then we plated the culture at $50^{\circ} \mathrm{C}$ on $\mathrm{TBAB}$ agar containing erythromycin 
and lincomycin. The pTVI plasmid cannot replicate at this temperature; the only cells that form colonies are those in which transposition of $\operatorname{Tn} 917$ to the bacterial chromosome has occurred. We pooled a few hundred such colonies, inoculated the pool into MMB, and induced the mixed population with mitomycin $\mathrm{C}$. The resulting $\mathrm{H} 2$ lysate was used to transduce strain CU1064 met $B 5$ to $\mathrm{MLS}^{\mathrm{R}}$. Among the rare transductants, several were able to release plaque-forming $\mathrm{H} 2$ phage that converted lysogens to resistance to erythromycin and lincomycin. Two such transductants have been studied further. One transductant, strain CU7049 metB5 (H2::Tn917) was used as a source of phage following mitomycin $C$ induction. The phage was used to produce other lysogens by selecting for MLSR. We also used phage prepared from CU7048 (probably identical to CU7049) to superinfect B. amyloliquefaciens strain CU8004, selecting for MLS ${ }^{\mathrm{R}}$. The resulting strain (labelled CU8060) released both $\mathrm{H} 2$ and $\mathrm{H} 2$ : : Tn 917 in approximately equal quantities; presumably it is lysogenic for both phages.

\section{Isolation of $\mathrm{H} 2 \mathrm{c} 21:$ : Tn 917 and $\mathrm{H} 2 \mathrm{c} 2 \mathrm{I}$}

On a plate containing about 2000 turbid plaques of $\mathrm{H} 2:: \operatorname{Tn} 917$ on CU3431, one clear plaque was seen. We purified the phage from this plaque. The progeny phage plaques were all clear. When lysates of this phage were used to transduce CU7004 to MLS ${ }^{\mathrm{R}}$, many transductants were found; thus the phage still carried at least part of the transposon. We have labelled it $\mathrm{H} 2 c 21:: \operatorname{Tn} 917$. This phage cannot lysogenize strain CU3431 or convert it to the Thy ${ }^{+}$or $\mathrm{MLS}^{\mathrm{R}}$ phenotypes.

We used $\mathrm{H} 2 c 21$ : : Tn917 to convert strain CU7004, an $\mathrm{H} 2$ lysogen, to MLS ${ }^{\mathrm{R}}$. An MLS colony from this conversion was purified, transferred to MMB, and induced to lyse with mitomycin C. Among the progeny phage were both clear-plaque and turbid-plaque phage particles. We purified phage clones from several clear plaques. Some of these could still convert CU7004 to MLS $^{\mathrm{R}}$; others could not. One of the clear-plaque derivatives that could not convert CU7004 to MLS ${ }^{\mathrm{R}}$ was labelled $\mathrm{H} 2 c 21$. We assume that it resulted from a recombination event between $\mathrm{H} 2 c 21:: \operatorname{Tn} 917$ and $\mathrm{H} 2$. $\mathrm{H} 2 c 21$ cannot lysogenize $B$. subtilis strains at detectable frequencies unless they are already lysogenic for $\mathrm{H} 2$ or $\mathrm{H} 2:$ : Tn 917 . Our evidence is compatible with the hypothesis that the $c 21$ mutation results in the inactivation of a $\mathrm{H} 2$ repressor.

\section{Specialized transduction by $\mathrm{H} 2$}

We first tried to determine if phage $\mathrm{H} 2$ could carry out generalized transduction in $B$. subtilis. Lysates of $\mathrm{H} 2$ induced from CU7004 could not transduce leuB6, $\arg A 2$ or $\operatorname{argC2}$ auxotrophs to prototrophy, but they did transduce metBS auxotrophs to $\mathrm{Met}^{+}$. This suggested that $\mathrm{H} 2$ could carry out specialized transduction, but not generalized transduction, and that its prophage attachment site (attH2) lay close to the met $^{+}$gene of strain CU7004.

Lysates of $\mathrm{H} 2$ induced from strain CU7004 usually contain about 100 transducing particles for $m e t B^{+}$for each $10^{6}$ plaque-forming particles. The number of transductants is reduced tenfold or more if the recipient is lysogenic for $\mathrm{H} 2$. The $i l v D 15$ and ilvA2 markers of $B$. subtilis, which are closely linked to $m e t B$, can also be transduced to prototrophy by $\mathrm{H} 2$ lysates from CU7004. Transduction frequencies are at least tenfold lower for $i l v D$ than for $m e t B$, and even less frequent for ilvA. This suggests that the $\mathrm{H} 2$ prophage lies between $\operatorname{trp} C$ and met $B$ on the $B$. subtilis chromosome. This position was confirmed by PBS1 mapping of the prophage (Table 2). Transduction of strain CU7004 by PBS1 phage grown in a Trp ${ }^{+}$non-lysogen, with selection for $\mathrm{Trp}^{+}$, resulted in the loss of the $\mathrm{H} 2$ prophage from about one-half of the transductants. We have not been able to demonstrate specialized transduction of the linked markers his $H 2$ or $\operatorname{tyr} A 2$ by $\mathrm{H} 2$ lysates, indicating that the prophage lies between $\operatorname{tyr} A$ and $m e t B$ (Piggot \& Hoch, 1985). The gene order in the region is $\operatorname{trpC}$-hisH-tyrA-attH2-metB-ilvD-thyB-ilvA-attSPB .

\section{High-frequency transducing lysates}

We transduced strain CU3431 metB5 thy All thyB 11 pla-l, selecting for $\mathrm{Met}^{+}$, with a lysate of $\mathrm{H} 2$ induced from strain CU7004. Among $17 \mathrm{Met}^{+}$transductants tested, 11 had become immune to the clear-plaque phage mutant $\mathrm{H} 2 c 21$ and prototrophic for thymine. We assume that some were doubly infected by $\mathrm{H} 2$ and by an imprecisely excised defective transducing phage $\mathrm{H} 2$ 
Table 2. Genetic location of the $H 2$ prophage by PBSI transduction

Transduction was achieved with strain CU1331 attH2 metB10 ilv A2 as donor and strain CU7004 trpC2

(H2) as recipient, with selection for $\operatorname{Trp}^{+}$.

\begin{tabular}{|c|c|c|c|c|}
\hline \multicolumn{4}{|c|}{ Phenotype } & \multirow[b]{2}{*}{ No. of colonies } \\
\hline Trp & $\mathrm{H} 2^{*}$ & Met & Ilv & \\
\hline+ & - & - & - & 49 \\
\hline+ & - & - & + & 7 \\
\hline+ & - & + & + & 8 \\
\hline+ & + & - & - & $2 \dagger$ \\
\hline \multirow[t]{2}{*}{+} & + & + & + & 34 \\
\hline & & & & otal \\
\hline
\end{tabular}

* The presence $(+)$ or absence $(-)$ of the $\mathrm{H} 2$ prophage was determined by testing for sensitivity of the transductants to phage $\mathrm{H} 2 c 21$.

† This class was generated by double recombination events or by re-infection of phage-cured cells on the transduction plates.

Table 3. H2 specialized transducing phages from various $B$. subtilis strains

Plaque-forming particles were measured on CU3431. Transducing particles were measured on CU2958 metB5 ilvD15 thyBS ilvA2 thy A5.

\section{Donor strain \\ and prophages}

CU7004 (H2)

CU7082 (H2) (H2 dmetB205)

CU7077 (H2) (H2 dilvD7)

CU7075 (H2) (H2 dilvA301)

\section{Plaque-forming particles $\left(\mathrm{ml}^{-1}\right)$}

$$
\begin{aligned}
& 1 \times 10^{8} \\
& 4 \times 10^{6} \\
& 2 \times 10^{6} \\
& 8 \times 10^{6}
\end{aligned}
$$

\begin{tabular}{|c|c|c|}
\hline $\mathrm{MetB}^{+}$ & IlvD ${ }^{+*}$ & $\begin{array}{l}\mathrm{IlvD}^{+} \text {and } \\
\operatorname{IlvA}^{+*}\end{array}$ \\
\hline $1 \times 10^{4}$ & $7 \times 10^{2}$ & $2 \times 10^{2}$ \\
\hline $1 \times 10^{6}$ & $<20$ & $<20$ \\
\hline $2 \times 10^{5}$ & $2 \times 10^{4}$ & $<20$ \\
\hline $2 \times 10^{5}$ & $1 \times 10^{5}$ & $2 \times 10^{4}$ \\
\hline
\end{tabular}

Transducing particles $\left(\mathrm{ml}^{-1}\right)$

* IlvD- strains require isoleucine and valine. $\operatorname{IlvA}^{-}$strains require isoleucine.

$\mathrm{d} m e t B$. When these 11 strains were induced with mitomycin $C$, three of the resulting lysates gave high-frequency transduction for met $B^{+}$. The ratios of plaque-forming particles to transducing particles were between $40: 1$ and $10: 1$. None of these three strains gave a lysate that transduced ilv $D$ or ilvA. One was kept as CU7071. Its genotype is metB5 thy AII thyB11 pla-1 (H2) $(\mathrm{H} 2$ $\mathrm{d}$ met $B 201$ ).

We constructed another strain that gave high-frequency transducing lysates for $m e t B^{+}$by a different protocol. We first infected strain CU2958 metB5 ilvD15 thyB5 ilvA2 thy A5 with phage $\mathrm{H} 2$ to produce a lysogen we call CU7040. We transduced CU7040 to $\mathrm{Met}^{+}$with an $\mathrm{H} 2$ lysate from strain CU7004 trpC2 (H2). Many of the transductants produced high-frequency transducing lysates for met $^{+}{ }^{+}$. One of those strains, CU7082, was kept for further study. We think that like CU7071, CU7082 carries two $\mathrm{H} 2$ prophages, one complete and one defective. Its genotype is metB5 ilvD15 thyB5 ilvA2 thy A5 (H2) (H2 dmetB205).

To construct $B$. subtilis strains capable of producing high-frequency transducing lysates for ilvD and ilvA, we transduced strain CU2958 metB5 ilvD15 thyB5 ilvA2 thy $A 5$ with a lysate from the $\mathrm{H} 2$ lysogen CU7004. Selection was for $\mathrm{Met}^{+}$, Thy ${ }^{+}$, and either IlvD ${ }^{+}$, or IlvD ${ }^{+}$and IlvA ${ }^{+}$. From the $\mathrm{Met}^{+}$, Thy ${ }^{+}, \mathrm{IlvD}^{+}$selection we isolated a strain, CU7077, that gives high-frequency transducing lysates for $m e t B^{+}$and $i l v D^{+}$. From the $\mathrm{Met}^{+}$, Thy ${ }^{+}$, IlvD ${ }^{+}$, IlvA ${ }^{+}$selection we isolated a strain, CU7075, that gives high-frequency transducing lysates for met $B^{+}$, ilv $D^{+}$and ilv $A^{+}$. We named the specialized transducing phages in CU7077 and CU7075, $\mathrm{H} 2 \mathrm{dilvD} 7$ and $\mathrm{H} 2$ dilvA301, respectively. Both of these strains, of course, are also lysogenic for complete $\mathrm{H} 2$ phage. Some characteristics of typical lysates of these strains, and of strains CU7004 (the H2 lysogen) and CU7082 (which gives high-frequency of transduction for $m e t B^{+}$) are given in Table 3. 
Table 4. Size estimation of bacteriophage H2 DNA

\begin{tabular}{ccccc} 
& \multicolumn{4}{c}{ Fragment sizes (kb) } \\
Fragment & SalI & PstI & AvaI & AvaII \\
A & 41 & 32 & 42.5 & $(110)^{*}$ \\
B & 38 & 17.5 & 38 & 19 \\
C & 21 & 17 & 23 & \\
D & 15.5 & 15 & 13 & \\
E & 10.5 & 12 & 8 & \\
F & 5.5 & 6.8 & 3.7 & \\
G & & 6.6 & 1.3 & \\
H & & 6.1 & & \\
I & & 5.1 & & \\
J & & 4.2 & & \\
X & & 2.0 & & \\
L & & 1.1 & & \\
M & & 1.0 & & \\
N & & 0.6 & & \\
Total & 131.5 & 127.0 & 129.5 & $(129.0)$
\end{tabular}

* Estimated from average size (129 kb; this does not include the AvalI value).

\section{Morphology of phage $\mathrm{H} 2$}

We purified phage $\mathrm{H} 2$ from mitomycin-C-induced lysates of strain CU7004. Electron micrographs demonstrated a phage with a polyhedral (possibly icosahedral) head $85 \mathrm{~nm}$ in diameter ( 35 measurements) and a flexible tail of about $17 \times 434 \mathrm{~nm}$ (20 and 16 measurements, respectively). This is consistent with the dimensions of Group III temperate phages of $B$. subtilis (SP $\beta, \rho-11, \phi 3 T$, SPR, etc.; see Dean et al., 1978; Warner et al., 1977; Rutberg, 1982; Zahler, 1982), although the tails of $\mathrm{H} 2$ are somewhat longer and thicker than those of the others.

The DNA of phage H2, and its DNA methylases

Bacteriophage $\mathrm{H} 2$ DNA was isolated, and digestion with several restriction enzymes revealed a linear DNA molecule with an average measured size of about $129 \mathrm{~kb}$ (Table 4). The size of the $\mathrm{H} 2$ genome is similar to those of the Group III temperate phages of $B$. subtilis (Cregg \& Ito, 1979; Dean et al., 1976, 1978; Fink \& Zahler, 1982). We used the methods of Fink et al. (1981) to produce a restriction enzyme map of the $\mathrm{H} 2$ genome, and compared it with the map of SP $\beta$ aligned so that the HaeIII DNA methylase activities of both phages lay in the left half of the molecules (Fig. 1 ; see below). DNA-DNA hybridization studies comparing $\mathrm{H} 2$ to the Group III phages $\mathrm{SP} \beta, \phi 3 \mathrm{~T}$ and SPR show that $\mathrm{H} 2$ is homologous to these phages; $\mathrm{SP} \beta, \phi 3 \mathrm{~T}$ and SPR are more closely related in Southern hybridizations to each other than any of them is to $\mathrm{H} 2$ (data not shown).

Trautner and his coworkers (see review, Gunthert \& Trautner, 1984) have shown that several of the Group III phages of $B$. subtilis encode DNA methylases that are expressed during the lytic growth cycle. Phage H2 DNA, isolated from phage grown in B. subtilis strain CU3431, is resistant to several restriction enzymes including BamHI, HaeIII, Fnu4HI and Bsp1286I (the target sequences of these enzymes are: GGATCC; GGCC; GCNGC; and GDGCHC respectively, where $D$ is $G, A$ or $T$ and $H$ is $C, A$ or $T$ ). As is true of the other members of this group of bacteriophages, the modification activities are expressed only during lytic development; the H2 prophage in lysogens such as CU7004 is sensitive to these restriction endonucleases.

We have cloned each of these modification activities from $\mathrm{H} 2$ phage DNA and have shown that they can be expressed in E. coli. Experiments have been done to determine the relatedness of these modification enzymes to each other and to the modification enzymes that have been studied from other bacteriophages of the group. These results will be published elsewhere. 


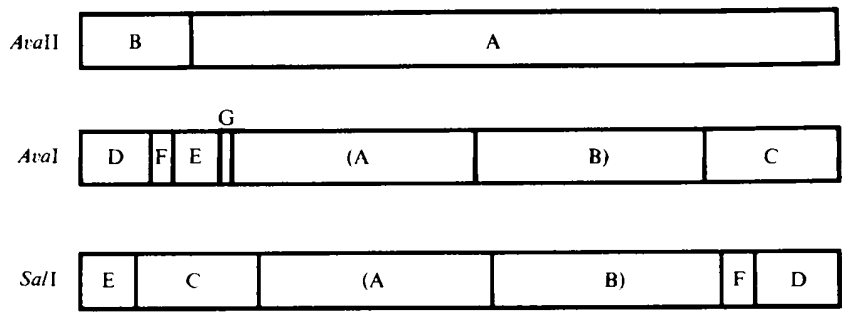

$\mathrm{H} 2$

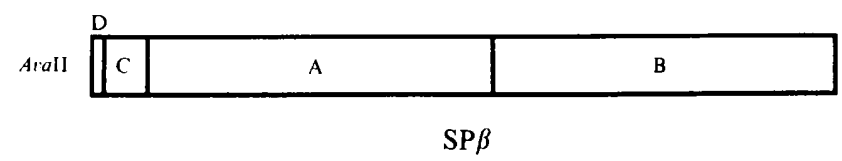

Fig. 1. Restriction endonuclease map of bacteriophage H2 DNA, aligned with the map of SP $\beta$ (Fink \& Zahler, 1982).

\section{DISCUSSION}

Bacteriophage $\mathrm{H} 2$, isolated from $B$. amyloliquefaciens strain $\mathrm{H}$, is related to the Group III temperate phages of $B$. subtilis. Morphologically it differs slightly from SP $\beta$ and $\phi 3 T$; its tail is thicker and longer. In unpublished experiments we have found that antiserum prepared against $\mathrm{SP} \beta c 1$, a clear-plaque mutant of SP $\beta$, cannot inactivate phage $\mathrm{H} 2$, and that SP $\beta c 1$ does not adsorb to $B$. amyloliquefaciens. Antiserum prepared against phage $\mathrm{H} 2$ does not inactivate $\mathrm{SP} \beta$. Thus, differences in tail structure are not unexpected.

The $\mathrm{H} 2$ genome consists of about $129 \mathrm{~kb}$ of linear DNA, very similar to the $126 \mathrm{~kb}$ reported for phage SP $\beta$ (Fink et al., 1981). When H2 lysogenizes $B$. subtilis, the prophage lies between the tyr $A$ and met $B$ genes on the bacterial chromosome. The prophage has thymidylate synthase activity; thymine auxotrophs of $B$. subtilis become prototrophic for thymine when they have been lysogenized by $\mathrm{H} 2$. When the prophage is induced with mitomycin $\mathrm{C}$, many defective phage particles containing the $m e t B$ gene are produced and can carry out specialized transduction. Smaller numbers of $\mathrm{H} 2$ particles carry the nearby ilvD and ilv $A$ genes. Highfrequency transducing lysates can be produced from bacteria doubly lysogenic for a defective transducing prophage and a complete $\mathrm{H} 2$ prophage; these lysates transduce met $B$, or met $B$ and $i l v D$, or met $B$, ilv $D$ and ilv $A$ in $B$. subtilis. We do not know where the $\mathrm{H} 2$ prophage lies on the $B$. amyloliquefaciens chromosome, and we do not have mutations in that species suitable for learning if met $B$ and the ilv genes can be transduced. Phage SP $\beta$ of $B$. subtilis can also carry out specialized transduction. Its DNA is partly homologous with that of phage $\mathrm{H} 2$ (Weiner and Zahler, unpublished results).

We produced some useful mutants of $\mathrm{H} 2$. One of them, $\mathrm{H} 2:: \operatorname{Tn} 917$, carries the $S$. faecalis transposon $\mathrm{Tn} 917$. From $\mathrm{H} 2:: \operatorname{Tn} 917$ we isolated a clear-plaque mutant, $\mathrm{H} 2 c 21:: \operatorname{Tn} 917$, that can still convert $\mathrm{H} 2$ lysogens to antibiotic resistance. ( $\mathrm{Tn} 917$ encodes an RNA methylase that protects Gram-positive bacteria from such antibiotics as erythromycin and lincomycin.) From such a converted strain, presumably carrying both $\mathrm{H} 2$ and $\mathrm{H} 2 c 21:: \operatorname{Tn} 917$, we isolated the recombinant phage $\mathrm{H} 2 c 21$. This clear-plaque phage cannot lysogenize phage-sensitive cells of $B$. subtilis and does not carry $\operatorname{Tn} 917$.

We were able to superinfect strain CU8004, the B. amyloliquefaciens strain $\mathrm{H}$ from which $\mathrm{H} 2$ was isolated, with $\mathrm{H} 2:: \operatorname{Tn} 917$. Thus we have introduced $\operatorname{Tn} 917$ into $B$. amyloliquefaciens, although not on a particularly useful vector. In the one case we have analysed, the antibioticresistant $B$. amyloliquefaciens released both $\mathrm{H} 2$ and $\mathrm{H} 2:: \operatorname{Tn} 917$ when it was induced. It is possible that the phage has multiple attachment sites on the chromosomes of both species of Bacillus. The fact that $\mathrm{H} 2 c 21:: \mathrm{Tn} 917$ can lysogenize $\mathrm{H} 2$ lysogens of $B$. subtilis suggests that the c2I mutation has inactivated a phage repressor but has not removed the repressor target sites. 
We have isolated some thirty auxotrophic mutants of CU8004 of many different phenotypes (unpublished experiments). Unfortunately, none of them has the $\mathrm{MetB}^{-}$, IlvD ${ }^{-}$or IlvA phenotype, so we do not know if $\mathrm{H} 2$ can give specialized transduction of those genes in $B$. amyloliquefaciens. Of course, the prophage site on the $B$. amyloliquefaciens chromosome may not be close to those genes; in fact, the order of genes on the $B$. amyloliquefaciens chromosome is unknown.

Phage $\mathrm{H} 2$ encodes proteins that protect its own DNA from certain restriction endonucleases: $B a m$ HI, HaeIII, Fnu4HI and Bsp1286I. The prophage DNA is not protected from these enzymes; the protective proteins are probably expressed only during vegetative growth of the phage. Protection from these enzymes is due to DNA methyltransferases encoded by the phage (unpublished observations). Trautner and his colleagues have similarly shown that related phages protect their DNA from HaeIII and from Fnu4HI by appropriate DNA methyltransferases that are expressed only by vegetative phages (Gunthert \& Trautner, 1984).

This work was supported by a grant from the Dow Chemical Company. We are grateful for useful conversations with H. E. Hemphill of Syracuse University. Bruce Carlton of the University of Georgia kindly sent us $B$. amyloliquefaciens strain $\mathrm{H}$.

\section{REFERENCES}

Anagnostopoulos, C. \& Spizizen, J. (1961). Requirements for transformation in Bacillus subtilis. Journal of Bacteriology 81, 741-746.

CreGG, J. M. \& ITO, J. (1979). A physical map of the genome of temperate phage Phi3T. Gene 6, 199-219.

Dean, D. H., OrRego, J. C., Hutchinson, K. W. \& Halvorson, H. O. (1976). New temperate bacteriophage for Bacillus subtilis: Rhol 1. Journal of Virology 29, 509-519.

Dean, D. H., ForT, C. L. \& HoCh, J. A. (1978). Characterization of temperate phages of Bacillus subtilis. Current Microbiology 1, 213-217.

Fernandes, R. A., DE Lencastre, H. \& ArCher, L. J. (1983). Three new temperate phages of Bacillus subtilis. Journal of General Microbiology 132, 661668.

Fink, P. S., Korman, R. Z., Odebralski, J. M. \& ZAHLER, S. A. (1981). Bacillus subtilis bacteriophage SP $\beta c I$ is a deletion mutant of SP $\beta$. Molecular and General Genetics 182, 514-515.

FINK, P. S. \& ZAHLER, S. A. (1982). Restriction fragment maps of the genome of Bacillus subtilis bacteriophage SP $\beta$. Gene 19, 235-238.

Gunthert, U. \& Trautner, T. A. (1984). DNA methyltransferases of Bacillus subtilis and its bacteriophages. Current Topics in Microbiology and Immunology 108, 11-22.

Neuhard, J., Price, A. R., Schack, L. \& Tomasson, E. (1973). Two thymidylate synthetases in Bacillus subtilis. Proceedings of the National Academy of Sciences of the United States of America 75, 1194 1198.

Piggot, P. J. \& Hoch, J. A. (1985). Revised genetic linkage map of Bacillus subtilis. Microbiological Reviews 49, 158-179.

Rosenthal, R., Toye, P. A., Korman, R. Z. \& ZAHLER, S. A. (1979). The prophage of SP $\beta c 2$ d $c i t K-1$, a defective specialized transducing phage of Bacillus subtilis. Genetics 92, 721-739.
RUTBERG, L. (1982). Temperate bacteriophages of Bacillus subtilis, In Molecular Biology of the Bacilli, vol. 1, pp. 247-268. Edited by D. Dubnau. New York: Academic Press.

TUCKER, R. G. (1969). Acquisition of thymidylate synthetase activity by a thymine-requiring mutant of Bacillus subtilis following infection by the temperate phage $\phi 3$. Journal of General Virology 4, 489-504.

WARD, J. B., JR \& Zahler, S. A. (1973). Genetic studies of leucine biosynthesis in Bacillus subtilis. Journal of Bacteriology 116, 719-726.

Warner, F. D., Kitos, G. A., Romano, M. P. \& HEMPHILl, H. E. (1977). Characterization of SP $\beta$ : a temperate bacteriophage from Bacillus subtilis 168M. Canadian Journal of Microbiology 23, 45-51.

WELKeR, N. E. \& CAMPBELL, L. L. (1967). Unrelatedness of Bacillus amyloliquefaciens and Bacillus subtilis. Journal of Bacteriology 94, 1124-1130.

Youngman, P. J., Perkins, J. B. \& Losick, R. (1983). Genetic transposition and insertional mutagenesis in Bacillus subtilis with Streptococcus faecalis transposon Tn917. Proceedings of the National Academy of Sciences of the United States of America 80, 23052309.

ZAHLER, S. A. (1982). Specialized transduction in Bacillus subtilis. In Molecular Biology of the Bacilli, vol. 1, pp. 269-305. Edited by D. Dubnau. New York: Academic Press.

ZAhleR, S. A., Korman, R. Z., Rosenthal, R. \& HEMPHILL, H. E. (1977). Bacillus subtilis bacteriophage SP $\beta$ : localization of the prophage attachment site, and specialized transduction. Journal of Bacteriology 129, 556-558.

ZahleR, S. A., Korman, R. Z., Thomas, C. \& OdebralsKi, J. M. (1987). Temperate bacteriophages of Bacillus amyloliquefaciens. Journal of General Microbiology 133, 2933-2935. 